\title{
PENYUSUNAN BAHAN AJAR UNTUK MENINGKATKAN KEMAMPUAN PENGGUNAAN KALIMAT EFEKTIF DALAM MENULIS KARYA ILMIAH BIDANG KEWARGANEGARAAN
}

\author{
Heni Heryani \\ STKIP Pasundan Cimahi \\ heniheryani65@gmail.com
}

\begin{abstract}
Material or teaching materials for effective sentences are found in Indonesian Language courses. Students really need real and continuous examples and exercises in order to use effective sentences in their scientific work. The lack of effective sentence lecture material cannot be separated from the use of teaching materials that are still inadequate. The formulation of the problem of this research is "How do the steps to compile instructional materials for effective sentences in writing scientific papers of PPKn Study Program Study Program students?" research. Effective sentence teaching materials are arranged based on the teaching material model used in the STKIP Pasundan Cimahi environment. In order for teaching materials to be relevant to the field of knowledge that students learn, examples of using effective sentences in the field of citizenship are added. In addition, the task of writing scientific papers is given so that students practice continuously. The results of the analysis and assessment of the scientific work of the experimental material teaching the effective sentence shows the following points. (1) The application of the chosen aspects of the word scientific work is very good in nine scientific works, the selection of words is in accordance with the function and meaning correctly (2) The application of the unity aspect in eleven scientific works is very good. (3) The application of the alignment aspect looks very good on seven scientific works because there are parallels of form, alignment of meaning, and alignment of the details of the right choices.

(4) The application of aspects of emphasis / assertiveness on sentences is found in one scientific work that has very good value. (5) The use of varied sentences is found in one scientific work very well. (6) Application of logical aspects to 24 good scientific works. (7) The application of the spelling rules to one scientific work is very good. (8) The application of the economical aspects of the five scientific works is very good because it uses words economically, wasteful words are avoided, there is no use of plural meaningful words put together in sentences.
\end{abstract}

Keywords: Teaching Materials, Effective Sentences, Scientific Work

\begin{abstract}
ABSTRAK
Materi atau bahan ajar kalimat efektif terdapat dalam mata kuliah Bahasa Indonesia. Mahasiswa sangat memerlukan contoh dan latihan yang nyata serta berkesinambungan agar dapat menggunakan kalimat efektif dalam
\end{abstract}




\section{Didaktik : Jurnal Pendidikan Guru Sekolah Dasar, ISSN : 24775673 \\ Sekolah Tinggi Keguruan dan IImu Pendidikan Subang Volume IV Nomor 1, Juli 2018}

karya ilmiah mereka. Kurangnya materi perkuliahan kalimat efektif tidak terlepas dari penggunaan bahan ajar yang masih belum memadai. Rumusan masalah penelitian ini adalah "Bagaimana langkah menyusun bahan ajar kalimat efektif yang tepat dalam menulis karya ilmiah mahasiswa Jurusan PIPS Prodi PPKn?" Penulis menggunakan metode deskriptif analitis yang berusaha menggambarkan data yang diteliti yang terjadi pada masa sekarang serta menguraikan aspek-aspek yang menjadi fokus penelitian. Bahan ajar kalimat efektif disusun berdasarkan model bahan ajar yang digunakan di lingkungan STKIP Pasundan Cimahi. Agar bahan ajar relevan dengan bidang ilmu yang dipelajari mahasiswa, contoh-contoh penggunaan kalimat efektif bidang kewarganegaraan ditambahkan. Selain itu, tugas menulis karya ilmiah diberikan agar mahasiswa berlatih secara berkesinambungan. Hasil analisis dan penilaian karya ilmiah uji coba bahan ajar kalimat efektif menunjukkan hal-hal berikut. (1) Penerapan aspek pilihan kata karya ilmiah sangat baik pada sembilan karya ilmiah, pemilihan katakata sudah sesuai dengan fungsi dan makna secara tepat (2) Penerapan aspek kesatuan dalam sebelas karya ilmiah sangat baik. (3) Penerapan aspek kesejajaran terlihat sangat baik pada tujuh karya ilmiah karena terdapat kesejajaran bentuk, kesejajaran makna, dan kesejajaran rincian pilihan yang tepat. (4) Penerapan aspek penekanan/ketegasan pada kalimat terdapat pada satu karya ilmiah yang bernilai sangat baik.(5) Penggunaan kalimat yang bervariasi terdapat pada satu karya ilmiah sangat baik. (6) Penerapan aspek kelogisan pada 24 karya ilmiah baik.(7) Penerapan kaidah ejaan pada satu karya ilmiah sangat baik. (8) Penerapan aspek kehematan pada lima karya ilmiah sangat baik karena menggunakan kata secara hemat, kata-kata mubazir dihindari, tidak ada penggunaan kata bermakna jamak disatukan dalam kalimat.

Kata Kunci: Bahan Ajar, Kalimat Efektif, Karya IImiah

\section{A. Pendahuluan}

Selama penulis mengajar di STKIP Pasundan Cimahi, penulis membaca berbagai karya ilmiah mahasiswa berbagai jurusan karena penulis mengajar mata kuliah Bahasa Indonesia sebagai mata kuliah umum. Materi atau bahan ajar kalimat efektif terdapat dalam mata kuliah Bahasa Indonesia tersebut.
Banyak keluhan yang dilontarkan oleh mahasiswa Jurusan PIPS Prodi PPKn mengenai materi perkuliahan kalimat efektif bahasa Indonesia yang masih berupa teori, sedangkan mahasiswa sangat memerlukan contoh dan latihan yang nyata serta berkesinambungan agar dapat menggunakan kalimat efektif 
dalam karya ilmiah mereka. Selain itu, kalimat efektif akan lebih kaya dan komprehensif jika didasarkan atas hasil penelitian yang faktual dari berbagai karya tulis ilmiah.

Kurangnya materi perkuliahan kalimat efektif tidak terlepas dari penggunaan bahan ajar yang masih belum memadai. Oleh sebab itu, materi atau bahan ajar kalimat efektif perlu disusun dengan memperhatikan kebutuhan mahasiswa sehingga mahasiswa dapat menerapkan kaidah-kaidah penggunaan kalimat efektif dalam karya ilmiah yang ditulisnya. Selain itu, materi atau bahan ajar yang disusun haruslah sesuai dengan bidang ilmu, yaitu bidang kewarganegaraan.

Berdasarkan latar belakang masalah di atas, maka rumusan masalah penelitian ini adalah:

1. Bagaimana penyusunan bahan ajar kalimat efektif yang tepat dalam menulis karya ilmiah mahasiswa Jurusan PIPS Prodi PPKn?

2. Bagaimana tanggapan mahasiswa Jurusan PIPS Prodi PPKn terhadap bahan ajar yang baru untuk peningkatan kemampuan penggunaan kalimat efektif dalam menulis karya ilmiah?

Penelitian ini bermanfaat untuk memperoleh deskripsi data yang diperlukan dan memperoleh bahan ajar kalimat efektif yang tepat yang dapat meningkatkan kemampuan mahasiswa dalam menulis karya ilmiah, serta untuk mengatasi kesulitan memberikan pemahaman dan keterampilan menggunakan kalimat efektif kepada mahasiswa. Anggapan dasar penelitian ini adalah bahan ajar yang tepat dibutuhkan agar keberhasilan pembelajaran dapat dicapai sesuai dengan tujuan pembelajaran.

\section{B. Landasan Teori}

\section{Penyusunan Bahan Ajar}

Proses belajar mengajar tidak akan lepas dari tugas dan peran pengajar dan pembelajar. Masingmasing memiliki posisinya sesuai dengan tugas dan perannya. Tugas dan peran ini saling mengisi selama proses belajar mengajar. Tidak ada satu pihak yang lebih 
besar peranannya karena keduanya berada dalam satu arah dan tujuan yang sama. Proses belajar mengajar tertumpu pada bagaimana pengajar memberi kemungkinan bagi peserta didik agar terjadi proses belajar mengajar yang efektif sehingga dapat mencapai tujuan yang ditetapkan. Sebelum menyusun bahan ajar yang akan disampaikan kepada siswa, perlu disusun perencanaan dan pengembangan pembelajaran agar proses belajarmengajar berjalan dengan efektif.

\section{Perencanaan \\ Pengembangan \\ Pembelajaran}

dan

Selain peran pengajar dan pembelajar, proses belajarmengajar yang berlangsung juga tidak terlepas dari perencanaan pembelajaran.

Perencanaan pembelajaran merupakan rancangan atau rencana proses dan kegiatan belajar-mengajar. Perencanaan pembelajaran juga merupakan suatu program bagaimana mengajarkan apa yang sudah dirumuskan dalam kurikulum, tujuan yang hendak dicapai, bahan apa yang harus dipelajari, metode apa yang akan digunakan, dan evaluasi apa yang akan dilakukan seluruhnya tertuang dalam perencanaan pengajaran (Iskandarwassid dan Sunendar, 2006: 193).

\section{Penetapan dan Pemilihan Bahan Ajar}

Komponen yang penting selain pengajar dan pembelajar dalam proses belajar-mengajar adalah materi atau bahan ajar (Iskandarwassid dan Sunendar, 2006: 196). Bahan ajar merupakan salah satu unsur penunjang keberhasilan dalam pembelajaran.

Bahan ajar atau materi pengajaran dapat dibedakan antara materi formal dan dan materi informal (Gulo dalam Yuliawati, 2006: 32). Materi formal adalah isi pelajaran yang terdapat dalam buku teks resmi (buku paket) di sekolah, sedangkan materi informal ialah bahan-bahan pelajaran yang bersumber dari lingkungan sekolah yang bersangkutan. Bahan-bahan yang bersifat informal ini dibutuhkan 
agarpengajaran lebih relevan dan aktual.

Sehubungan dengan materi atau bahan ajar di atas, ada beberapa hal yang perlu diperhatikan dalam menetapkan materi atau bahan ajar, yaitu:

a. materi pelajaran hendaknya sesuai dengn kurikulum sehingga dapat menunjang tercapainya tujuan instruksional,

b. materi pelajaran hendaknya sesuai dengan tingkat pendidikan dan perkembangan peserta didik pada umumnya,

c. materi pelajaran hendaknya terorganisasi secara sistematik dan berkesinambungan, dan

d. materi pelajaran hendaknya mencakup hal-hal yang bersifat faktual maupun konseptual. Materi dan bahan pengajaran yang ditetapkan dengan merujuk pada tujuan-tujuan instruksional yang ingin dicapai. Materi yang diberikan bermakna bagi peserta didik dan merupakan bahan yang betulbetul penting, baik dilihat dari tujuan yang ingin dicapai maupun fungsinya untuk mempelajari bahan berikutnya (Iskandarwassid dan Sunendar, 2006: 211).

Selanjutnya dikemukakan bahwa sebaiknya materi ini disediakan secara lengkap dan lebih banyak dari yang diperkirakan supaya dalam pelaksanaan pengajaran tidak kekurangan bahan. Pada bagian lainnya dikemukakan pula bahwa dalam upaya menyusun dan mengembangkan materi pelajaran ini perlu dipertimbangkan kriteria berikut ini.

a. Materi atau bahan itu tepat untuk pencapaian tujuan pengajaran.

b. Bahan ajar itu bermanfaat, artinya disesuaikan dengan kebutuhan nyata dan tingkatan peserta didik.

c. Materi atau bahan pelajaran harus menarik.

d. Materi atau bahan ajar harus sesuai dengan batas kemampuan peserta didik.

Dengan demikian, penetapan atau pemilihan bahan ajar atau materi pelajaran yang tepat sangat penting agar seluruh perencanaan 
dan pelaksanaan pengajaran tercapai secara optimal.

\section{Metode Penelitian}

Penulis menggunakan metode deskriptif analitis yang berusaha menggambarkan data yang diteliti yang terjadi pada masa sekarang serta menguraikan aspek-aspek yang menjadi fokus penelitian. Pernyataan tersebut sejalan dengan pernyataan Surakhmad (1982: 139) bahwa metode penelitian deskriptif tertuju pada pemecahan masalah yang ada pada masa sekarang. Ciri-ciri metode deskriptif adalah (1) memusatkan diri pada masalahmasalah aktual dan (2) data yang dikumpulkan mula-mula disusun, dijelaskan, kemudian dianalisis. Data yang diperoleh dalam penelitian ini dideskripsikan kemudian dilakukan penafsiran dan penganalisisan terhadap deskripsi data penelitian untuk memperoleh deskripsi yang mendalam.

Data penelitian ini berupa data tertulis yang terdapat dalam makalah mahasiswa semester kedua Jurusan PIPS Prodi PPKn, data pelaksanaan perkuliahan di kelas, data karya ilmiah yang dibuat pada awal perkuliahan dengan bahan ajar yang selama ini digunakan, dan data karya ilmiah yang dibuat oleh mahasiswa setelah bahan ajar yang baru tersusun dan diujicobakan.

Penelitian ini dilaksanakan pada mahasiswa STKIP Jurusan PIPS Program Studi PPKn yang sedang mengambil mata kuliah Bahasa Indonesia pada semester kedua. Sesuai dengan tujuan penelitian ini, pengambilan sampel dilakukan secara purposive, yakni pengambilan sampel atas tujuan tertentu.

\section{Hasil Penelitian dan} Pembahasan

1. Landasan Penyusunan Bahan Ajar Kalimat Efektif

Berdasarkan permasalahan yang dibahas sebelumnya, dipandang perlu untuk menindaklanjutinya dengan menyusun bahan ajar kalimat efektif bagi mahasiswa Jurusan PIPS Prodi PPKn yang relevan 
dan aktual. Hal itu dilakukan atas dasar penemuan yang ada, bahwa karya ilmiah mahasiswa memiliki karakteristik tersendiri.

Bahan ajar kalimat efektif yang selama ini dipelajari sangat diperlukan oleh mahasiswa agar dapat menulis karya ilmiah sesuai dengan bidang ilmunya. Akan tetapi, bahan ajar tersebut masih perlu dilengkapi dengan contoh penggunaan kalimat efektif dalam wacana bidang kewarganegaraan.

\section{Penyusunan Bahan Ajar Kalimat Efektif}

Bahan ajar kalimat efektif disusun berdasarkan model bahan ajar yang digunakan di lingkungan STKIP Pasundan Cimahi. Agar bahan ajar relevan dengan bidang ilmu yang dipelajari mahasiswa, contoh-contoh penggunaan kalimat efektif bidang kewarganegaraan ditambahkan. Selain itu, tugas menulis karya ilmiah diberikan agar mahasiswa berlatih secara berkesinambungan. Topik dan subtopik bahan ajar yang disusun disajikan di bawah ini, sedangkan bahan ajar secara lengkap disajikan dalam lampiran.

Bahan Ajar Kalimat Efektif Bidang Kewarganegaraan

Topik/Pokok Bahasan

Kalimat Efektif

Subtopik/Subpokok Bahasan

1. Definisi Kalimat Efektif

2. Syarat-syarat

Kalimat Efektif

Subtopik 1 Definisi Kalimat Efektif Subtopik 2 Syarat-syarat Kalimat Efektif
A. Pilihan Kata (Diksi)

1. Ketepatan Pilihan Kata

1) penggunaan kata sesuai dengan fungsi dan makna

2. Kesesuaian Pilihan Kata

1) penggunaan kata-kata sesuai dengan kesempatan atau situasi, keadaan masyarakat, nilai-nilai sosial, kata-kata baku dan nonbaku, dan sasaran tulisan.

2) Penggunaan istilah secara cermat.

B. Struktur Kalimat Efektif

1. Kesatuan

1) satu ide pokok

2) dua atau lebih ide pokok

3) kesatuan pilihan 
4) kesatuan pertentangan

2. Kesejajaran (Paralelisme)

1) kesejajaran bentuk

2) kesejajaran makna

3) kesejajaran rincian pilihan

3. Kehematan

1) tidak mengulang subjek

2) menghindari superordinat pada hiponim kata

3) menghindari kesinoniman dalam satu kalimat

4) menghindari pemakaian kata depan dan kata penghubung yang tidak perlu

5) tidak menjamakkan kata-kata yang berbentuk jamak

4. Ketegasan/Penekanan

1) mengubah posisi kata atau frasa dalam kalimat menjadi pada awal kalimat

2) mengulang kata yang sama apabila diperlukan

3) menggunakan partikel -lah, kah, pun

4) menggunakan kata keterangan seperti bahkan, jadi

5) mengubah posisi subjek, predikat, objek, atau keterangan

6) mengubah kalimat aktif menjadi kalimat pasif

5. Kevariasian
1) variasi kalimat panjang dan kalimat pendek

2) variasi pembukaan kalimat dengan:

a. frasa keterangan

b. frasa benda

c. frasa kerja

3) variasi pola kalimat

Contoh : $\mathrm{S}-\mathrm{P}-\mathrm{O}-\mathrm{K}$ menjadi $\mathrm{K}$ $-\mathrm{S}-\mathrm{P}-\mathrm{O}$ $\mathrm{S}-\mathrm{P}-\mathrm{O}$ menjadi $\mathrm{P}-$ $\mathrm{O}-\mathrm{S}$

4) variasi jenis kalimat

a. kalimat berita

b. kalimat tanya

c. kalimat perintah

5) variasi bentuk kalimat aktif dan kalimat pasif

C. Logika/Penalaran dalam Kalimat

1) kebenaran menarik kesimpulan umum

2) kebenaran menarik kesimpulan khusus

3) kebenaran persamaan (analogi)

4) kebenaran alasan (argumentasi)

D. Ejaan

1. Penulisan huruf

2. Penulisan kata

3. Pemakaian tanda baca 


\begin{tabular}{lll}
\multicolumn{2}{c}{ Berdasarkan silabus } & f. Ciri-ciri kalimat efektif \\
perkuliahan Bahasa Indonesia & g. Kesatuan dan kehematan \\
yang digunakan oleh dosen, materi & h. Keanekaragaman dan \\
perkuliahan kalimat efektif yang & penekanan \\
selama ini dipelajari di Jurusan & 4. PP : Ceramah, diskusi, \\
PIPS Prodi PPKn sama dengan & memberi tugas, latihan di kelas \\
materi perkuliahan yang dipelajari & tentang kalimat \\
di jurusan lainnya yang terdapat di & berdasarkan \\
STKIP Pasundan Cimahi. Materi & jenisnya, serta fungsinya untuk \\
kalimat efektif dipelajari & komunikasi lisan \\
berdasarkan buku-buku rujukan & tulisan.
\end{tabular}
tanpa dijabarkan lebih lanjut berdasarkan contoh-contoh kalimat dalam bacana bidang kewarganegaraan. Materi perkuliahan kalimat efektif yang dipelajari selama ini adalah berikut ini.

Materi Perkuliahan Kalimat Efektif 1. PB : Kalimat Bahasa Indonesia 2. TK : Memperluas pengetahuan dan meningkatkan keterampilan mengenai pembuatan dan penggunaan kalimat bahasa Indonesia yang baik dan benar

3. UMK:

5. PHB : Menganalisis bentuk kalimat pada media massa cerpen bahasa Indonesia, termasuk jenis dan fungsi kalimatnya

6. SR : Kalimat Efektif Bahasa Indonesia karangan Sabarti, 1985, penerbit UT Jakarta.

Penulisan Karya IImiah dengan Bahasa Indonesia yang Benar, karangan

E.Z. Arifin, 1987, penerbit Media Sarana Perkasa

a. Pengertian kalimat

b. Unsur kerangka kalimat Jakarta.

c. Struktur kalimat

d. Kalimat majemuk

e. Kalimat efektif

Komposisi karangan Gorys Keraf, 1971, penerbit Nusa Indah Ende Flores 
Kaidah Bahasa Indonesia

karangan Slamet Mulyana, 1969, penerbit

Jembatan Jakarta.

Kalimat Efektif karangan

Abdul Rozak, 1985, penerbit

Gramedia Jakarta.

PB : Pokok Bahasan

TK : Tujuan Perkuliahan

UMK : Uraian Materi Perkuliahan

PP : Pendekatan Pembelajaran

PHB : Penilaian Hasil Belajar

SR : Sumber Rujukan

Materi perkuliahan yang

dideskripsikan di atas belum

dilengkapi dengan contoh kalimat dalam wacana bidang kewarganegaraan.

\section{Uji Coba Bahan Ajar Kalimat}

\section{Efektif}

Untuk mengetahui kontribusi bahan ajar terhadap peningkatan kemampuan menggunakan kalimat efektif dalam karya ilmiah, dilaksanakan perkuliahan pada mahasiswa semester 2 Jurusan PIPS Prodi PPkn yang sedang mengambil mata kuliah Bahasa Indonesia dengan jumlah mahasiswa 28 orang. Seperti yang telah dikemukakan pada bagian pendahuluan, bahwa materi atau bahan ajar kalimat efektif terdapat dalam mata kuliah bahasa Indonesia. Penulis memandang materi kalimat efektif merupakan materi yang berkontribusi tinggi terhadap penulisan karya ilmiah mahasiswa Jurusan PIPS Prodi PPKn yang memiliki karakteristik tersendiri.

Topik kalimat efektif ini merupakan topik yang penting agar mahasiswa dapat menerapkannya dalam menulis karya ilmiah bidang kewarganegaraan. Topik-topik lainnya seperti sistematika penulisan karya ilmiah sudah disampaikan oleh dosen sebelum pelaksanaan uji coba bahan ajar. Selain itu, topik tersebut dapat dipelajari pula dalam mata kuliah Metode Penelitian Karya IImiah oleh dosen lainnya. Sesuai dengan silabus, perkuliahan ini dilaksanakan setelah mahasiswa menempuh Ujian Tengah Semester.

Pelaksanaan perkuliahan kalimat efektif dengan bahan ajar yang baru ini diserahkan 


\section{Didaktik : Jurnal Pendidikan Guru Sekolah Dasar, ISSN : 24775673 \\ Sekolah Tinggi Keguruan dan IImu Pendidikan Subang Volume IV Nomor 1, Juli 2018}

sepenuhnya pada dosen mata kuliah bahasa Indonesia sebagai dosen pembina, yaitu Drs. H. Amir Suyatna, penulis turut hadir untuk mengobservasi perkuliahan.

Untuk keperluan penelitian ini penulis mengobservasi perkuliahan dalam empat kali pertemuan. Setiap pertemuan berlangsung selama 100 menit. Berikut ini dideskripsikan dan dianalisis pelaksanaan perkuliahan kalimat efektif dengan bahan ajar hasil penelitian yang mencakup proses perkuliahan, penilaian karya ilmiah sebagai indikator hasil uji coba, dan tanggapan dosen mata kuliah bahasa Indonesia terhadap bahan ajar kalimat efektif.

Aspek yang diobservasi dalam perkuliahan adalah aktivitas dosen dan mahasiswa. Aktivitas dosen meliputi tiga bagian yaitu kegiatan pendahuluan, kegiatan inti, dan kegiatan penutup. Kegiatan pendahuluan mencakup apersepsi dan penyampaian tujuan. Kegiatan inti meliputi unsur materi, penggunaan metode, penugasan di kelas, latihan menulis di kelas, pengoreksian tulisan. Bagian penutup meliputi rangkuman dan tindak lanjut. Untuk kegiatan mahasiswa aspek yang diamati adalah merespon materi (bertanya kepada dosen, mengajukan komentar, berdiskusi dengan teman), mengerjakan tugas/latihan menulis, serta menilai dan memperbaiki tulisannya.

Pada pertemuan pertama, dosen memberikan penjelasan tentang bahan ajar kalimat efektif yang akan diajarkan pada perkuliahan minggu yang akan datang. Pada tahap ini dosen memberikan tugas membuat makalah bidang kewarganegaraan yang harus dikumpulkan pada pertemuan kedua. Hal ini dilakukan untuk mengetahui kemampuan awal mahasiswa menggunakan kalimat efektif dalam karya ilmiah.

Pada pertemuan kedua, dosen memberikan penjelasan tentang subtopik Definisi Kalimat Efektif, subtopik Pilihan Kata, dan subtopik Ejaan dalam bahan ajar yang baru. Selama perkuliahan berlangsung mahasiswa mengajukan pertanyaan tentang cara memilih kata yang tepat, 
lazim, dan benar serta bagaimana membuat kalimat yang efektif sesuai dengan kaidah ejaan.

Pada pertemuan ketiga, dipelajari subtopik Struktur Kalimat Efektif Bidang Kewarganegaraan. Dosen memberikan penjelasan struktur kalimat efektif harus memiliki syarat kesatuan, kehematan, kesejajaran, ketegasan, dan kevariasian. Selain itu, diberikan contoh-contoh kalimat bidang kewarganegaraan yang tidak memenuhi keefektifan yang diambil dari bahan ajar. Mahasiswa diminta pendapatnya tentang kalimat-kalimat yang tidak efektif tersebut. Mahasiswa terlihat begitu antusias mendengarkan penjelasan dosen dan mengemukakan pendapatnya masing-masing tentang contoh kalimat bidang kewarganegaraan yang diberikan dosen. Kalimatkalimat yang tidak efektif dibahas bersama-sama.

Pertemuan

keempat, dipelajari subtopik Logika/Penalaran dalam Kalimat. Pertemuan diawali dengan penjelasan tentang pentingnya kelogisan dalam kalimat. Pada pertemuan ini mahasiswa ditugasi membaca bahan ajar dengan subtopik kelogisan. Selanjutnya dosen menjelaskan kesalahankesalahan logika dalam kalimat bidang kewarganegaraan yang masih banyak terdapat dalam karya ilmiah mahasiswa yang ditulis pada pertemuan pertama. Apabila kalimat tidak sesuai dengan logika akan terdapat kalimat yang salah nalar. Dosen menjelaskan bahwa kesalahan logika/nalar bisa diakibatkan oleh kesalahan menarik kesimpulan umum, kesalahan menarik kesimpulan khusus, kesalahan analogi, dan kesalahan argumentasi. Selanjutnya dosen memberikan contoh kalimat yang tidak sesuai dengan logika yang terdapat dalam bahan ajar. Mahasiswa berdiskusi untuk memperbaiki kalimat-kalimat sehingga menjadi kalimat efektif sesuai dengan logika kalimat.

Dalam kegiatan diskusi terlihat mahasiswa sangat antusias untuk memahami kalimat yang sesuai dengan logika walaupun 
masih mengalami kesulitan untuk membedakan mana kalimat yang sesuai dengan logika dan yang tidak sesuai dengan logika. Selain itu, dosen juga memberikan contoh kalimat umum yang tidak masuk akal (logis) yang sering diungkapkan secara lisan. Hal itu dilakukan agar mahasiswa dapat membedakannya dengan kalimat dalam tulisan, yakni karya ilmiah. Setelah diskusi dilaksanakan, dosen menyimpulkan hasil diskusi tentang kalimat yang memnuhi kelogisan dengan memberikan latihan membuat kalimat efektif bidang kewarganegaraan. Pada akhir perkuliahan mahasiswa diberi tugas lagi untuk membuat makalah bidang kewarganegaraan yang harus dikumpulkan tiga hari setelah pertemuan tersebut.

\section{Hasil Pemberlakuan Bahan} Ajar Kalimat Efektif

Setelah bahan ajar kalimat efektif diujicobakan pada mahasiswa, dilakukan penilaian terhadap karya ilmiah mahasiswa yang telah dikumpulkan pada akhir perkuliahan. Hal itu dilakukan untuk mengetahui kemampuan akhir mahasiswa menggunakan kalimat efektif dalam karya ilmiah.

Proses penilaian karya ilmiah hasil uji coba sama seperti proses penilaian pada karya ilmiah sebelum bahan ajar kalimat efektif diujicobakan, yaitu menggunakan sistem penilaian skala interval yang terdapat pada instrumen keempat. Hasil analisis dan penilaian karya ilmiah uji coba bahan ajar kalimat efektif menunjukkan hal-hal berikut.

a. Penerapan aspek pilihan kata karya ilmiah sangat baik pada sembilan karya ilmiah, pemilihan kata-kata sudah sesuai dengan fungsi dan makna secara tepat. Pemilihan kata juga sudah sesuai dengan aturan baku dan tidak baku, dan nilai-nilai sosial. Penggunaan istilah sudah tepat juga sesuai dengan kelaziman. Sebanyak 19 karya ilmiah memperlihatkan penggunaan pilihan kata yang baik karena sudah menggunakan kata secara tepat dan sesuai. Selain itu, terdapat penggunaan istilah yang lazim 
sehingga pembaca dapat

memahaminya dengan tepat.

b. Penerapan aspek kesatuan dalam sebelas karya ilmiah sangat baik. Hal ini terlihat pada ide atau gagasan kalimat sudah jelas. Unsur-unsur wajib seperti subjek dan predikat dituliskan secara eksplisit. Sebanyak empat belas karya ilmiah menerapkan aspek kesatuan yang baik, artinya aspek kesatuan telah diterapkan walaupun ada kalimat yang memperlihatkan kesalahan kesatuan tidak mengganggu makna. Terdapat tiga karya ilmiah yang memiliki nilai cukup karena ada beberapa kalimat yang tidak memiliki aspek kesatuan.

c. Penerapan aspek kesejajaran terlihat sangat baik pada tujuh karya ilmiah karena terdapat kesejajaran bentuk, kesejajaran makna, dan kesejajaran rincian pilihan yang tepat. Pada delapan belas karya ilmiah baik karena aspek kesejajaran sudah diterapkan dengan baik. Terdapat tiga karya ilmiah yang cukup baik karena adanya beberapa kesalahan dalam penggunaan bentuk kata dan rincian pilihan

d. Penerapan aspek kehematan pada lima karya ilmiah sangat baik karena menggunakan kata secara hemat, kata-kata mubazir dihindari, tidak ada penggunaan kata bermakna jamak disatukan dalam kalimat. Terdapat 18 karya ilmiah yang bernilai baik karena telah menggunakan kata-kata dengan hemat dengan baik. Karya ilmiah yang memiliki beberapa kesalahan dalam aspek kehematan berjumlah 5 dan bernilai cukup baik.

e. Penerapan aspek penekanan/ketegasan pada kalimat terdapat pada satu karya ilmiah yang bernilai sangat baik. Penerapan penekanan seperti mengubah posisi kata atau frasa dalam kalimat, menggunakan partikel, dan menggunakan bentuk pasif sudah terlihat pada beberapa karya ilmiah. Terdapat 21 karya ilmiah yang baik dalam 
menerapkan aspek penekanan.

Pada 6 karya ilmiah penerapan aspek ketegasan cukup baik. Ini diketahui dengan masih adanya kesalahan penggunaan penekanan dalam kalimatkalimat sehingga kalimat menjadi tidak efektif.

f. Penggunaan kalimat yang bervariasi terdapat pada satu karya ilmiah sangat baik. Hal ini terlihat pada kevariasian pola kalimat, kevariasian pembukaan kalimat, dan kevariasian bentuk aktif pasif. Pada 25 karya ilmiah penerapan aspek kevariasian baik Terdapat dua karya ilmiah yang cukup baik karena masih ada kesalahan kevariasian terutama variasi dalam pola kalimat dan variasi bentuk.

g. Penerapan aspek kelogisan pada 24 karya ilmiah baik. Kalimat yang digunakan memenuhi kebenaran menarik kesimpulan umum, kebenaran menarik kesimpulan khusus, kebenaran analogi, dan kebenaran argumentasi. Pada empat karya ilmiah cukup baik dalam menerapkan aspek kelogisan walaupun ada kalimat yang tidak logis tetapi tidak mengganggu keseluruhan makna kalimat.

h. Penerapan kaidah ejaan pada satu karya ilmiah sangat baik. Hal itu terlihat dalam menempatkan huruf besar dan huruf kecil dengan tepat, penulisan huruf miring pada kata-kata asing. Penulisan kata pun menunjukkan ketepatan dalam membedakan kata depan di dan ke dengan imbuhan didan ke- dalam kalimat. Selain itu, tanda baca dipakai dengan tepat. Terdapat 23 karya ilmiah yang bernilai baik. Terdapat empat karya ilmiah bernilai cukup karena masih terdapat beberapa penggunaan huruf yang salah, beberapa penulisan kata yanga salah, dan beberapa pemakaian tanda baca yang salah. Hasil penilaian secara keseluruhan terdapat dalam tabel di pada halaman berikut.

Berdasarkan nilai yang diperoleh, dari 28 karya ilmiah terdapat 5 karya ilmiah bernilai $A$, 18 karya ilmiah bernilai $B$, dan 5 
karya ilmiah bernilai C. Persentase nilai $A=17,86 \%$, nilai $B=64,28$ $\%$, dan nilai $\mathrm{C}=17,86 \%$. Persentase nilai A sama dengan nilai $C$, dan persentase nilai $B$ lebih tinggi dibandingkan dengan persentase nilai C. Dengan demikian, model bahan ajar kalimat efektif berkontribusi tinggi terhadap kemampuan menulis karya ilmiah.

Persentase nilai karya ilmiah pada akhir perkuliahan mengalami peningkatan dari nilai karya ilmiah pada akhir perkuliahan. Nilai A pada kemampuan awal 3,57 \% pada kemampuan akhir 17, $86 \%$, Nilai B pada kemampuan awal $17,86 \%$ pada kemampuan akhir $64,28 \%$. Nilai C pada kemampuan awal $64,28 \%$ pada kemampuan akhir 17,86 \%. Nilai D pada kemampuan awal 14, 28 \% pada kemampuan akhir $0 \%$.

\section{Tanggapan Dosen dan}

Mahasiswa terhadap Bahan Ajar Kalimat Efektif

Untuk mengetahui tanggapan dosen dan mahasiswa terhadap model bahan ajar kalimat efektif untuk meningkatkan kemampuan menulis karya ilmiah dilakukan wawancara pada dosen dan penyebaran angket kepada mahasiswa.

Tanggapan dosen terhadap bahan ajar kalimat efektif sangat baik. Dosen berpendapat bahan ajar kalimat efektif yang sesuai dengan bidang ilmu mahasiswa sangat membantu pemahaman menerapkan aspek-aspek kalimat efektif dalam menulis karya ilmiah Penguasaan aspek pilihan kata, struktur kalimat efektif, dan penguasaan aspek logika sangat diperlukan agar karya ilmiah dipahami dengan tepat oleh pembacanya.

Dari angket yang diisi mahasiswa yang mengikuti perkuliahan dengan bahan ajar kalimat efektif yang baru diperoleh tanggapan yang dapat dilihat pada tabel pada halaman berikut.

Tabel 1.

Tanggapan Mahasiswa terhadap Bahan Ajar Kalimat Efektif

\begin{tabular}{|c|c|c|c|c|c|c|}
\hline \multicolumn{2}{|r|}{$\begin{array}{l}\text { Pertanyaan tentang Bahan Ajar/Materi } \\
\text { kalimat Efektif }\end{array}$} & A & B & C & D & \multirow{2}{*}{\begin{tabular}{|l|}
$\begin{array}{c}\text { Keteranga } \\
\mathbf{n}\end{array}$ \\
$\begin{array}{l}\text { A: sangat } \\
\text { bermanf } \\
\text { aat }\end{array}$ \\
B:
\end{tabular}} \\
\hline 1 & $\begin{array}{l}\text { Kontribusi bahan ajar/materi } \\
\text { perkuliahan kalimat efektif terhadap } \\
\text { pengetahuan dan pemahaman } \\
\text { mahasiswa tentang karya ilmiah } \\
\text { bidang kewarganegaraan }\end{array}$ & 8 & 19 & 1 & & \\
\hline 2 & $\begin{array}{l}\text { Kontribusi bahan ajar kalimat efektif } \\
\text { terhadap keterampilan memilih kata } \\
\text { dan istilah dalam menulis karya ilmiah }\end{array}$ & 13 & 13 & 2 & & $\begin{array}{l}\text { bermanf } \\
\text { aat } \\
\text { C: cukup }\end{array}$ \\
\hline 3 & $\begin{array}{l}\text { Kontribusi bahan ajar kalimat efektif } \\
\text { terhadap keterampilan menerapkan } \\
\text { aspek kesatuan dalam menulis karya } \\
\text { ilmiah }\end{array}$ & 7 & $\mid 16$ & 5 & & $\begin{array}{l}\text { bermanf } \\
\text { aat } \\
\text { D: kurang }\end{array}$ \\
\hline 4 & $\begin{array}{l}\text { Kontribusi bahan ajar kalimat efektif } \\
\text { terhadap keterampilan menerapkan } \\
\text { aspek kesejajaran dalam menulis } \\
\text { karya ilmiah }\end{array}$ & 9 & 12 & 7 & & $\begin{array}{l}\text { bermanf } \\
\text { aat }\end{array}$ \\
\hline 5 & $\begin{array}{l}\text { Kontribusi bahan ajar kalimat efektif } \\
\text { terhadap keterampilan menerapkan } \\
\text { aspek kehematan dalam menulis } \\
\text { karva ilmiah }\end{array}$ & 5 & 18 & 5 & & \\
\hline
\end{tabular}


Berdasarkan hasil tanggapan mahasiswa di atas, pernyataan $B$ lebih banyak dibandingkan dengan pernyataan $A$ dan $C$, sedangkan pernyataan $D$ tidak ada yang memilinnya, sehingga dapat disimpulkan bahwa bahan ajar berkontribusi tinggi terhadap keterampilan mahasiswa menerapkan aspek-aspek kalimat efektif dalam menulis karya ilmiah.

\section{E. Kesimpulan}

Berdasarkan hasil analisis hasil penelitian ini dapat disimpulkan hal-hal berikut.

1. Penyusunan bahan ajar kalimat efektif yang tepat untuk Jurusan
PIPS Prodi PPKn adalah bahan ajar yang relevan dan aktual, yaitu sesuai dengan bidang ilmu mahasiswa. Bahan ajar kalimat efektif perlu disempurnakan/dilengkapi penjabarannya dengan contohcontoh kalimat dalam wacana bidang kewarganegaraan, sehingga mahasiswa dapat berlatih menerapkannya dalam karya ilmiah.

2. Tanggapan yang diberikan dosen dan mahasiswa terhadap bahan ajar kalimat efektif yang baru sangat baik. Bahan ajar tersebut dapat digunakan dalam perkuliahan dan berkontribusi tinggi untuk meningkatkan penggunaan kalimat efektif dalam karya ilmiah mahasiswa Jurusan PIPS Prodi PPKn.

Dari hasil temuan dan kesimpulan penelitian ini direkomendasikan beberapa hal. Pertama, kemampuan menggunakan kalimat efektif dalam menulis karya ilmiah merupakan salah satu komponen yang harus dimiliki oleh mahasiswa Jurusan PIPS Prodi 
PPKn. Kedua, bahan ajar kalimat efektif yang digunakan harus relevan dan aktual. Ketiga, bahan ajar kalimat efektif yang dilengkapi dengan contoh kalimat dalam

\section{DAFTAR PUSTAKA}

Akhdiah, Sabarti, dkk. 1985. Buku Materi 4: Kalimat Efektif Bahasa Indonesia. Jakarta : Universitas Terbuka.

Alwasilah, A. Chaedar. 2003. Pokoknya Kulaitatif. Jakarta : PT Kiblat Buku Utama.

Alwi, Hasan, dkk. 2003. Tata Bahasa Baku Bahasa Indonesia. Jakarta : Balai Pustaka.

Arifin, E. Zaenal. 1987. Penulisan Karangan Ilmiah dengan Bahasa Indonesia yang Benar. Jakarta : Media Sarana Perkasa.

Arifin, E. Zaenal. 1998. Dasardasar Penulisan Karangan IImiah. Jakarta : Gramedia.

Arifin, E. Zaenal. dan Hadi, Farid. 1993. 1001 Kesalahan Berbahasa. Jakarta: Akademika Presindo.

Arifin, E. Zaenal dan Tasai, S. A. 2006. Cermat Berbahasa Indonesia. Jakarta: Akademika Pressindo.

Arikunto, Suharsimi. 2002. Prosedur Penelitian: Suatu Pendekatan Praktek. Jakarta : Rineka Cipta.

Badudu, J.S. 1993. Inilah Bahasa Indonesia yang Benar II. Jakarta : PT Gramedia. wacana bidang kewarganegaraan perlu digunakan dalam perkuliahan di Jurusan PIPS Prodi PPKn untuk meningkatkan penggunaan kalimat efektif dalam karya ilmiah.

Badudu, J.S. 1993. Inilah Bahasa Indonesia yang Benar III. Jakarta : PT Gramedia.

Badudu, J.S. 1993. Inilah Bahasa Indonesia yang Benar IV. Jakarta : PT Gramedia.

Chaer, Abdul. 2007. Kajian Bahasa: Struktur Internal, Pemakaian, dan Pemelajaran. Jakarta : Rineka Cipta.

Departemen Pendidikan Nasional Universitas Pendidikan Indonesia. 2006. Pedoman Penulisan Karya Imiah. Bandung.

Djamarah, Syaiful Bahri dan Zain, Aswan. 2006. Strategi Belajar Mengajar. Jakarta: Rineka Cipta.

Gula, W. 2002. Strategi Belajar Mengajar. Jakarta: PT Gramedia.

Hamalik, Oemar. 2001. Proses Belajar Mengajar. Jakarta : Bumi Aksara.

Hamalik, Oemar. 2003. Perencanaan Pengajaran Berdasarkan Pendekatan Sistem. Jakarta : Bumi Aksara.

Heryati, Y. 2002. Keefektifan Program dan Pelaksanaan Perkuliahan MKU Bahasa Indonesia dalam Menulis Karya Ilmiah. Tesis pada PPS UPI Bandung: tidak diterbitkan. 
Hidayat, K. dan Rahmina, I. 1991. Perencanaan Pengajaran Bahasa Indonesia. Bandung: Bina Cipta.

Iskandarwassid dan Sunendar, Dadang. 2006. Strategi Pembelajaran Bahasa. Diktat Kuliah. Bandung: SPS UPI.

Keraf, Gorys. 1980. Komposisi. Ende Flores: Nusa Indah.

Keraf, Gorys. 1985. Diksi dan gaya Bahasa. Jakarta: PT Gramedia.

Komara, Endang. 2004. Metode Penulisan Karya IImiah. Bandung: Multazam.

Kurniawan, Kh. 1995. Pemakaian Bahasa Indonesia Ragam Tulis IImiah (Studi Deskriptif Analitik terhadap Tesis Mahasiswa PPS IKIP Bandung. Tesis pada PPS IKIP Bandung: tidak diterbitkan.

Moleong, L.J. 2005. Metodologi Penelitian Kualitatif (Edisi IV). Yogyakarta: Rake Sarasin.

Mukhtar. 2008. Bimbingan Skripsi, Tesis, dan Artikel Ilmiah:Panduan Berbasis Penelitian Kuantitatif Lapangan dan Perpustakaan. Jakarta : Gaung Persada Press.

Priyanto, Imam J. 2008. "Menulis Artikel dengan Bahasa Efektif". Pikiran Rakyat. Bandung.

Pusat Pembinaan dan Pengembangan Bahasa. 2006. Pedoman Umum Ejaan Bahasa Indonesia yang Disempurnakan \& Pedoman Umum Pembentukan Istilah,
Cetakan X. Bandung : Yrama Widya.

Putrayasa, I.B. 2007. Kalimat Efektif (Diksi, Struktur, dan Logika). Bandung : Refika Aditama.

Rahayu, Minto. 2007. Bahasa Indonesia di Perguruan Tinggi. Jakarta Grassindo.

Razak, Abdul. 1985. Kalimat Efektif. Jakarta : PT Gramedia.

Rusyana, Yus. 1984. Bahasa dan Sastra dalam Gamitan Pendidikan. Bandung : CV Dipenogoro.

Sofyan, A. Nero. 2006. "Ihwal Teknik Penulisan Karya Ilmiah". Bahasa dan Sastra. KumpulanTulisan untuk Prof. Dr. H. J.S. Badudu pada hari ulang tahunnya yang ke 80 . Bandung : ISI, Jurusan Sastra Indonesia Fasa Unpad.

Sudjana, Nana. 2003. Tuntunan Penyusunan Karya IImiah. Bandung : Sinar Baru Adgensindo.

Sugiyono. 2005. Statitistika Untuk Penelitian. Bandung : Alfabeta.

Sugiyono. 2006. Metode Penelitian Pendidikan : Pendekatan Kualitatif, Kualitatif, dan $R$ $\& D$. Bandung : Alfabeta.

Sugono, Dendy. 1987. Berbahasa Indonesia dengan Benar. Jakarta : Puspa Swara.

Sugono, Dendy. 2003. Buku Praktis Bahasa Indonesia 1. Jakarta : Pusat Bahasa.

Sugono, Dendy. 2003. Buku Praktis Bahasa Indonesia 2. Jakarta : Pusat Bahasa. 
Sujaie, Zubaedah. 2006. Model Pembelajaran Klausa

Relatif Bahasa Indonesia dengan Teknik Rekursif Diagram. Bandung :

Program Pascasarjana UPI: tidak diterbitkan.

Sukmadinata, N.S. 2006. Metode Penelitian Pendidikan. Bandung : Remaja Rosdakarya.

Surakhmad, W. 1989. Pengantar Penelitian IImiah Dasar. Metode dan Teknik. Bandung: Tarsito.

Suyatna, A. 2007. Silabus Perkuliahan Bahasa Indonesia. Cimahi: STKIP Pasundan.

Syamsuddin, A.R. 1992. Wacana : Teori - Analisis Pengajaran. Bandung : Mimbar Pendidikan dan Seni. FPBS UPI.

Syamsuddin, A.R. dan Damaianti,V. 2006. Metode Penelitian Pendidikan Bahasa. Bandung

Remaja Rosdakarya.

Tarigan, Henry G. 1995. Analisis Kesalahan Berbahasa. Bandung : Angkasa.

Tarigan, Henry G. dan Tarigan, Djago. 1995. Pengajaran Analisis Kesalahan Berbahasa. Bandung: Angkasa.

Yuliawati, Sri N.2006. Studi Penyusunan Bahan Ajar Tata Tulis Laporan Berdasarkan Kompentensi, Materi Perkuliahan, dan Tugas Akhir. Tesis pada SPS UPI Bandung : tidak diterbitkan. 